DOI: $10.21802 / \operatorname{artm} .2020 .3 .15 .222$.

УДК 611.711.8-089-053

\title{
РОЗДУМИ ПРО КЛАСИФІКАЦІЙНІ ОЗНАКИ ПІЛОНІДАЛЬНОЇ ХВОРОБИ У ДІТЕЙ
}

\author{
В.С. Конопліцький, Р.В. Шавлюк
}

Вінницький національний медичний університет ім. М.I. Пирогова, кафедра дитячої хірургї,
м. Вінниця, Украӥна,
ORCID ID: 0000-0001-9525-1525, e-mail: vkonoplytsky@gmail.com

Резюме. Досі не розроблено єдиної концепції щодо причини виникнення пілонідальної хвороби, можливості її моделювання та зрозумілої єдиної класифікації, що є ключем до грунтовного розуміння цієї патології. Уніфікована класифікація пілонідальної хвороби повинна враховувати розвиток, перебіг та особливості клінічних форм, за рахунок та на основі чого формується клінічний діагноз, що допомагає обрати найбільш оптимальний індивідуальний спосіб та план лікування.

Мета роботи: опрацювати клінічно орієнтовані класифікаційні ознаки пілонідальної хвороби 3 урахуванням особливостей дитячого віку.

Результати дослідження. Шляхом об єднання досвіду попередників, власних досліджень та роздумів нами запропоновано клінічно орієнтовані класифікаційні ознаки захворювання у дітей на основі особливостей етіопатогенезу, притаманних для цього віку пацієнтів. Для цього були враховані основні відмінності дитячої групи пацієнтів від осіб дорослого віку: неможливість через вікові особливості тривалого перебігу захворювання, наявність морфо-метричних особливостей будови зовнішнього анального сфінктеру, наявність незрілої мезенхімоподібної тканини у порожнині пілонідальної кісти.

\section{Висновки:}

1. У сучасній хірургії дитячого віку існує нагальна необхідність у розробці та впровадженні в клінічну практику уніфікованих класифікаційних ознак пілонідальної хвороби.

2. Класифікаційні ознаки пілонідальної хвороби у дітей мають полягати у наявності низки морфологічних, етіопатогенетичних, анатомічних та клінічних відмінностей від осіб дорослого віку.

3. Використання розроблених класифікаційних ознак пілонідальної хвороби у дітей дозволить визначити клінічні варіанти перебігу захворювання та обрати найбільш оптимальну тактику хірургічного лікування.

Ключові слова: пілонідальна хвороба, діти, класифікація, дитяча хірургія.

Вступ. Досвід сучасної медичної науки свідчить про те, що найкращі результати лікування досягаються за умов можливості моделювання патологічного процесу, а також існування його класифікації, тривале клінічне існування якої переконливо доводить те, що існує теоретичне та практичне розуміння більшості аспектів патології, яке забезпечує задовільні результати діагностики і лікування конкретного захворювання.

На жаль, для пілонідальної хвороби (ПХ) на сьогоднішній день не існує відтворюваної експериментальної моделі та відсутня загальноприйнята класифікація, що негативно впливає на можливість досягати бажаних результатів у лікуванні цієї підступної хвороби, як у дорослих, так і в дитячому віці. Також відсутні однозначно визнані погляди на етіопатогенез захворювання, яке в своїй природі походження та існування містить вроджені та набуті чинники [16, 19].

Поняття ПХ досить широке і складається 3 комплексу патологічних проявів, які формуються під впливом несприятливих анатомо - фізіологічних факторів (вроджених і набутих) та зовнішніх чинників. При цьому кінцевим морфологічним субстратом реалізації ПХ є формування пілонідальної кісти [21].

Класифікація будь-якого захворювання, в тому числі і ПХ, повинна враховувати розвиток, перебіг та особливості клінічних форм, за рахунок та на основі чого формується клінічний діагноз, який допомагає обрати найбільш оптимальний індивідуальний спосіб та план лікування.

У вітчизняній та зарубіжній фаховій літературі існує досить багато класифікацій ПХ, але в основному вони стосуються висвітлення лише окремих чинників захворювання або базуються на зовнішніх проявах патології крижово-куприкової ділянки.

Крім того, в представлених класифікаціях існують різні погляди на хворобу через певну термінологічну плутанину. Ми підтримуємо думку О.С. Цеми та С.В. Цеми (2018), про доцільність використання одного загальновизнаного терміну, який має відповідний англомовний еквівалент, а саме "пілонідальна хвороба" або "пілонідальна кіста" 3 англомовними відповідниками, загальновизнаними у світовій медичній літературі, відповідно "pilonidal disease" та "pilonidal cyst" [21]. Через існування великої кількості термінів для визначення цього захворювання створюються незручності в трактуванні походження хвороби, діагностиці, лікуванні та тлумаченні результатів лікування, коли безпосередньо прояви ПХ помилково визначаються в якості ऑï "стадій розвитку" і навпаки. Особливо цей факт чітко простежується у класифікаціях, де фігурує термін "епітеліальний куприковий хід". 
Вперше окремі ознаки ПХ описав у 1847 р. A.W. Anderson у листі до редакції "Бостонського медичного хірургічного журналу" під назвою "Волосся, витягнуте із виразки", в якій автор привів спостереження кісти в куприковій ділянці, вмістом якої було волосся. В подальшому, у 1854 р. J.M. Warren надав більш детальні описи цієї патології та сформулював рекомендації щодо хірургічного лікування патологіï, a R.M. Hodges у 1880 р. дав назву хворобі "пілонідальний синус" [15].

Враховуючи існуючі логістичні недоречності, ми спробували створити універсальну схему ознак ПХ у дітей на основі об'єднання іiї різних чинників формування, перебігу та результатів реалізації.

Мета роботи: на основі накопиченого більш ніж за 150 річну історію захворювання фактичного матеріалу опрацювати клінічно орієнтовані класифікаційні ознаки пілонідальної хвороби 3 урахуванням особливостей дитячого віку.

Матеріали та методи: у роботі опрацьовані усі наявні на сьогоднішній день опубліковані концепції виникнення пілонідальної хвороби, варіанти ऑї перебігу та пропозиції формування класифікацій цієї патології. Були досліджені найбільш «популярні» теорії розвитку захворювання, як закордонних, так i вітчизняних авторів. На основі цих досліджень проведено глибокий аналіз їх результатів задля оцінювання можливості формування єдиної системи класифікації пілонідальної хвороби.

Результати дослідження. С.3. Оганесян (1970) виділив гострий та хронічний перебіг захворювання. М. Bearlley (1954) виділяв неускладнений період, стадію ускладнень без вторинних нориць, період формування вторинних нориць та періоди рецидиву захворювання, а в 1978 р. А.А. Заремба розділив перебіг ПХ на безсимптомний період, період клінічних проявів та період одужання.

У 70-90 pp. XX ст. T.G. Allen-Mersh та M.J. Notaras запропонували класифікаційні стадії розвитку патології: 1. Пілонідальний абсцес - формується у випадку нагноєння волосяного фолікула; 2. Пілонідальний синус - гнійник самостійно розкривається латеральніше від міжсідничної складки, формується вторинний норицевий отвір, всередині синусу запалення набуває хронічного характеру із періодичними загостреннями; 3. Перианальний пілонідальний синус - мається на увазі рецидив після радикального хірургічного лікування за рахунок хибного формування грануляцій; 4. Перианальний пілонідальний синус - розповсюдження інфекції в бік відхідника 3 можливим подальшим гнійним запаленням перианальної ділянки [1, 13].

У 1988 р. Ю.В. Дульцев та В.Л. Ривкін запропонували класифікацію на основі типу запалення: 1. Епітеліальний куприковий хід без клінічних проявів. 2. Гостре запалення епітеліального куприкового ходу: інфільтративна стадія; абсцедування. 3. Хронічне запалення епітеліального куприкового ходу: інфільтративна стадія; рецидивуючий абсцес; гнійна нориця. 4. Ремісія запалення епітеліального куприкового ходу [2].

В.К. Гобеджишвілі із співавт. (2000) розробили класифікацію за ступенями складності гнійних ускладнень: І ст. - первинні або вторинні нориці сіднично-крижово-куприкової ділянки розташовуються в міжсідничній складці або не $>2$ см вбік від неї; II ст. - первинні нориці сіднично-крижовокуприкової ділянки із розташуванням зовнішніх норицевих отворів не $>2$ см від міжсідничної складки; III ст. - вторинні нориці сіднично-крижовокуприкової ділянки розташовуються не $>2$ см від міжсідничної складки; IV ст. - вторинні нориці 3 множинними норицевими отворами, розлогими інфільтратами, некрозами шкіри, які розташовані в ділянці внутрішнього напівкола сідниць; V ст. - вторинні нориці, розлогі інфільтрати, які розташовані в ділянці зовнішнього напівкола сідниць та за іiі межами [22].

Турецький дослідник E. Tezel (2007) запропонував уніфікований класифікаційних підхід до визначення певних анатомічних ознак при ПХ, а саме при визначенні складності будови пілонідальної кісти, так званий "navicular concept". Назва запропонованого підходу походить від терміну "navicular area" (човникоподібна ділянка), яким автор позначив ділянку в глибині міжсідничної ділянки, яка обмежена 3 обох сторін умовною лінією (navicular line), яка відповідає межі співставлення сідниць у вертикальному положенні пацієнта. На основі запропонованих анатомічних орієнтирів було розподілено пілонідальні кісти на прості (локалізація в межах navicular area) та складні (елементи первинних або вторинних норицевих ходів, що виходять за межі navicular area або знаходяться в межах anal triangle (ділянка, обмежена верхівкою куприка та сідничними буграми, що відповідає ретроанальній частині міжсідничної складки) (рис. 1).

Для визначення хірургічної тактики в 2010 р. B.I. Помазкін систематизував норицеві форми ПХ за двома ступенями важкості (проста та складна), які залежать від поширення патологічного процесу та розташування вторинних норицевих ходів відносно міжсідничної складки, "висоти" розташування сідниць, де за "високі" сідниці приймались критерії: глибина міжсідничної складки над найбільш низько розташованим первинним норицевим отвором $>3 \mathrm{~cm}$, кут міжсідничного заглиблення $<30^{\circ}[11,14]$.

За даними вимірів С.С. Корабліної (2014) [10], розподіл конфігурації сідниць по "висоті" залежить від окремих лінійних розмірів та певних взаємовідношень анатомічних чинників сідничнокрижово-куприкової ділянки.

Низька конфігурація сідниць характеризується високою локалізацією первинного норицевого отвору над заднім краєм анального отвору у відкритій по всій довжині міжсідничній складці (рис. 2). 


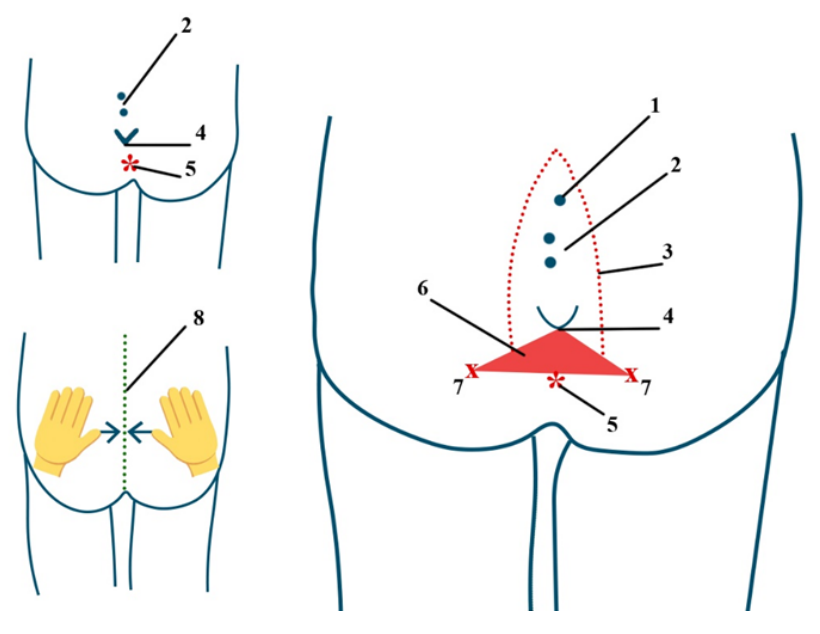

Рис. 1. Схема дефініцій човникоподібної ділянки: 1 - navicular area; 2 - зовнішні отвори норицевих ходів; 3 - латеральний край човникоподібної ділянки; 4 - верхівка куприка; 5 - анальний отвір; 6 - анальний трикутник ("anal triangle"); 7 - сідничні бугри; 8 - умовна лінія ("navicular line") [20].
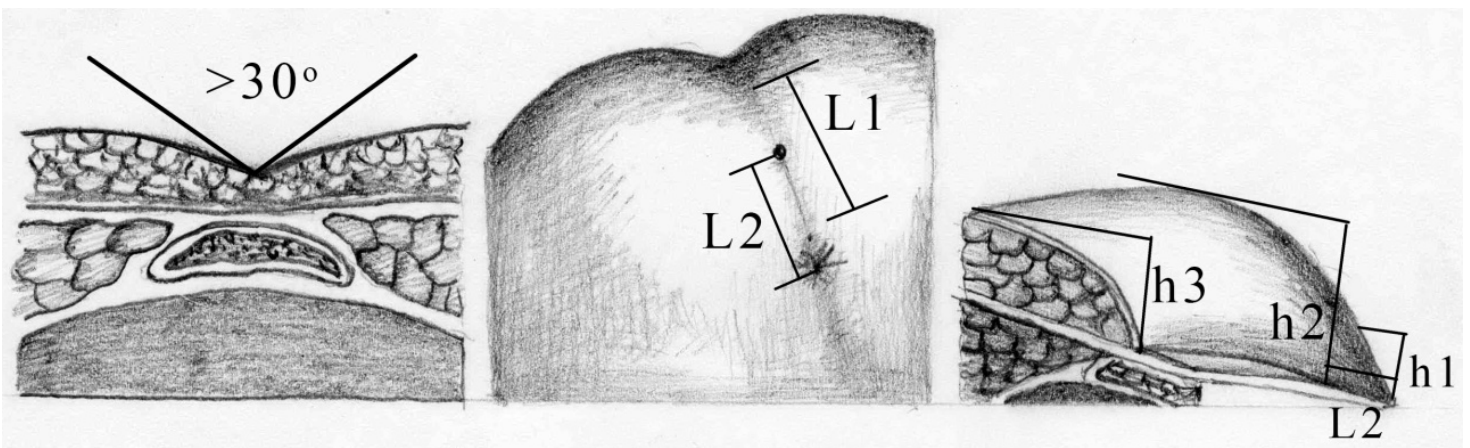

Рис. 2. Схема низької (пласкої) конфігурації сідниць: $l_{1}-$ довжина міжсідничної складки ( $\approx$ 8,3 см), $\mathbf{l}_{2}$ - відстань від краю анального отвору до первинного норицевого отвору $(\approx 8,4$ см$)$. Максимальна висота міжсідничного заглиблення над: h $_{1}$ краєм анального отвору $(\approx 4,0$ см$), h_{2}-$ проксимальним первинним норицевим отвором $(\approx 2,3$ см $), h_{3}-$ крижово-куприковим зчленуванням $(\approx 1,7$ см$)$.

Середня конфігурація характеризується більш високою локалізацією первинного норицевого отвору відносно заднього краю анального отвору в міжсідничній складці, яка має більшу ширину у своїй верхній частині (рис. 3).
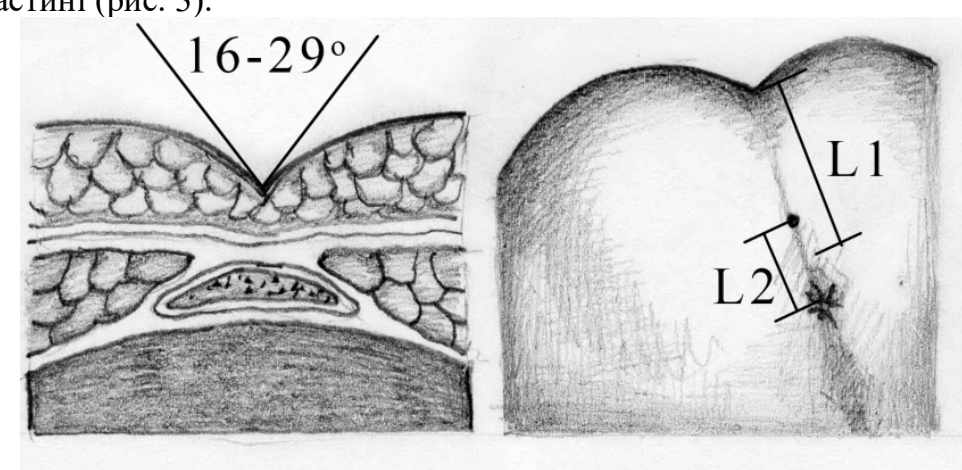

Висока конфігурація сідниць характеризується локалізацією первинного норицевого отвору в глибині міжсідничної складки в безпосередній близькості від заднього краю анального отвору (рис. 4).

Рис. 3. Схема середньої конфігурації сідниць: $l_{1}-$ довжина міжсідничної складки $(\approx 10,2$ см $), \mathbf{l}_{2}-$ відстань від краю анального отвору до первинного норицевого отвору $(\approx 6,3$ см). Максимальна висота міжсідничного заглиблення над: $\mathrm{h}_{1}$ - краєм анального отвору $(\approx 5,4$ см$), \mathbf{h}_{2}-$ проксимальним первинним норицевим отвором $(\approx 4,5$ см$), h_{3}-$ крижово-куприковим зчленуванням $(\approx 3,1 \mathrm{~cm})$ 

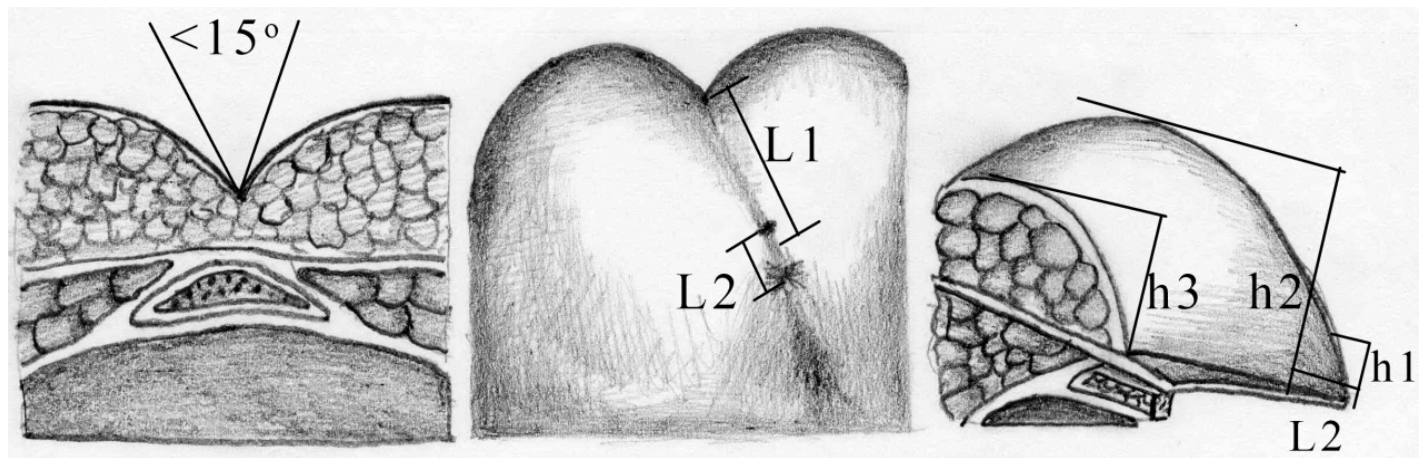

Рис. 4. Схема високої конфігурації сідниць: $l_{1}-$ довжина міжсідничної складки $(\approx 12,1 \mathrm{~cm}), \mathbf{l}_{2}-$ відстань від краю анального отвору до первинного норицевого отвору $(\approx 3,5$ см). Максимальна висота міжсідничного заглиблення над: $\mathbf{h}_{1}$ - краєм анального отвору $(\approx 8,8 \mathrm{~cm}), \mathbf{h}_{2}-$ проксимальним первинним норицевим отвором $(\approx 6,4 \mathrm{~cm}), \mathrm{h}_{3}-$ крижово-куприковим зчленуванням $(\approx 4,5$ см) [10]

За розміром та формою гнійників, наявністю і локалізацією вторинних ходів, Е.П. Рудін та співав. (2011) виділили 4 варіанти перебігу ПХ: 1 - початкові прояви запального процесу (припухлість, гіперемія та болючість в ділянці зовнішнього норицевого отвору); 2 - запальний процес в стадії формування абсцесу (припухлість на протязі всього норицевого ходу, флуктуація в проекції зовнішнього норицевого отвору з гнійними виділеннями); 3 - абсцедування по всьому обсягу кісти із наявністю додаткових вторинних нориць; 4 - розповсюдження запального процесу за межі куприкових ходів у вигляді флегмони крижово-куприкової ділянки та наявністю множинних нориць [19].

На основі етіопатогенезу ПХ та виявлених морфологічних особливостей I.А. Лурін та співав. (2013) виділили наступні стадії перебігу патології:

1. Гостра ПХ: гострий гнійний фолікуліт; гострий пілонідальний абсцес: фаза інфільтрації, фаза абсцедування. 2. Хронічна ПХ: з формуванням пілонідального норицевого ходу (в тому числі так званий "безсимптомний" епітеліальний куприковий хід); з формуванням вторинних норицевих ходів, як результат дренування гострого пілонідального абсцесу збоку від дна міжсідничної складки. 3. Рецидивна ПХ післяопераційний рецидив пілонідальної кісти [12].

Ali Guner (2016) запропонував класифікацію ПХ за ступенями їі важкості та складністю будови пілонідальної кісти: I ступінь - поодинокий первинний норицевий хід на дні міжсідничної складки, при відсутності вторинних норицевих ходів; II ступінь декілька первинних норицевих ходів, при відсутності вторинних норицевих ходів (II а ст. - 2-3 первинних норицевих ходів на дні міжсідничної складки, II b ст. - > 3-х норицевих ходів на дні міжсідничної складки); III ступінь - крім первинних норицевих ходів наявність 1-2 вторинних гнійних нориць 3 однієї сторони від дна міжсідничної складки; IV ступінь - крім первинних норицевих ходів наявність $>2$ вторинних гнійних нориць 3 обох сторін від міжсідничної складки; R ступінь - післяопераційний рецидив після оперативного втручання [4].

Деякі автори в своїх класифікаціях виділяють первинну рубрику -"пілонідальна хвороба без клінічних проявів", вважаючи при цьому, що такі пацієнти практично здорові, та не потребують оперативної допомоги $[17,18]$.

Зважаючи на проведені дослідження в період з 2012 по 2016 pp., O. Irkorucu запропонував класифікацію ПХ, відштовхуючись від думки про її переважно вроджений етіопатогенез: I тип - вроджений норицевий хід на дні міжсідничної складки; II тип поодинокий вроджений норицевий хід з будь-якої сторони міжсідничної складки; III тип - вроджені норицеві ходи 3 обох сторін від міжсідничної складки; IV тип - складна ПХ із вродженими норицевими ходами на дні та 3 обох сторін від міжсідничної складки; $\mathrm{V}$ - рецидивний перебіг ПХ [5, 6].

На основі класифікації E. Tezel в 2017 p. D.Ö. Karakaş iз співавт., запропонували розподіл ПХ за анатомічною локалізацією запальних проявів хвороби: тип IA - наявність єдиного норицевого ходу в міжсідничній складці; тип IB - наявність більше одного норицевого ходу в міжсідничній складці; тип II - локалізація норицевих ходів від міжсідничної складки до сідничних ділянок; тип IIIA - локалізація норицевих ходів від міжсідничної складки до поперекової ділянки; тип IIIВ - локалізація норицевих ходів від міжсідничної складки до перианальної ділянки; тип IV - складний пілонідальний синус (локалізація норицевих ходів від міжсідничної складки до сідничної та/або перианальної ділянок); тип $\mathrm{V}$ - рецидивуючий пілонідальний синус; тип VI - позакрижовокуприкова локалізація синусу (пупкова, міжпальцьова, статева (penis aбo vulva), ділянка грудної клітки, повік і т.п. або змішана) (рис. 5) [7]. 


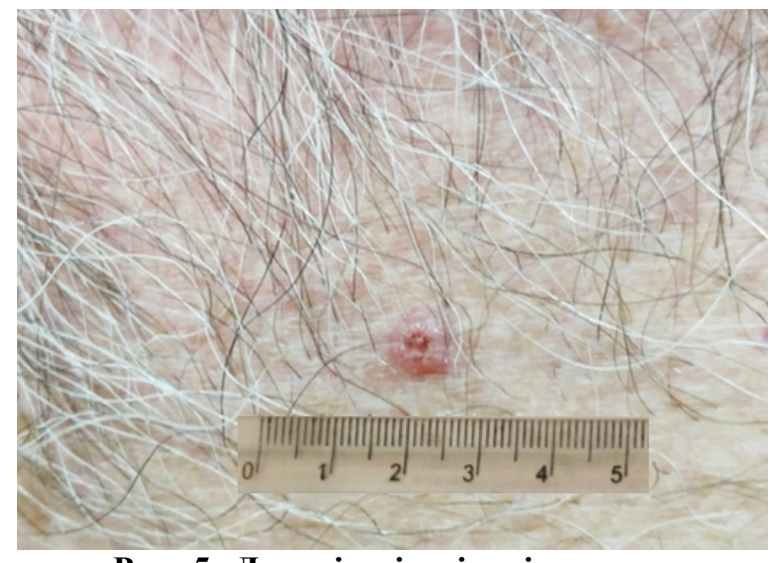

Рис. 5. Локалізація пілонідального синусу
У 2017 р. Т.Н. Зубайдов [23] запропонував класифікацію складних форм пілонідальних нориць: I ступінь - наявність одного норицевого ходу, крім первинного вогнища, на відстані $>2$ см від міжсідничної складки без додаткових гнійних запливів; II ступінь - наявність 2 норицевих ходів 3 різних боків, крім первинного вогнища, на відстані $>2 \mathrm{~cm}$ від міжсідничної складки без додаткових гнійних запливів; III ступінь наявність 3 та більше норицевих ходів 3 різних боків, крім первинного вогнища, на відстані >2см від міжсідничної складки із вираженими рубцями та інфільтратами навколо зовнішніх норицевих отворів або наявність нориць на такій же відстані із додатковими гнійними запливами (рис. 6). на грудній клітці

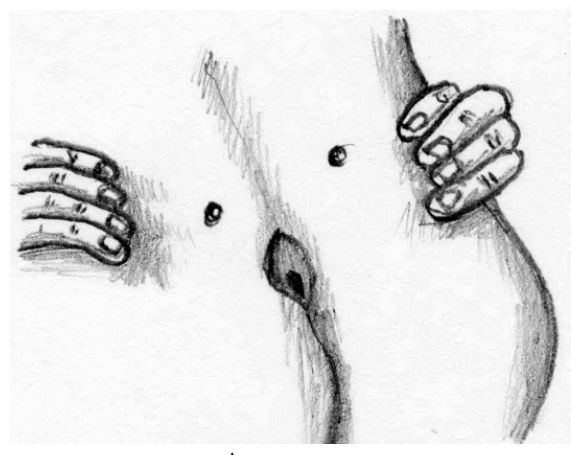

A

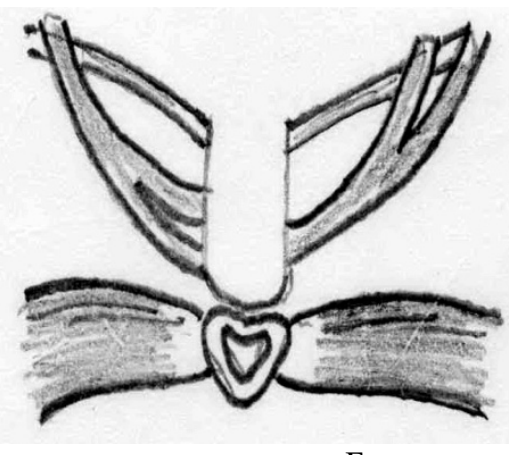

Б

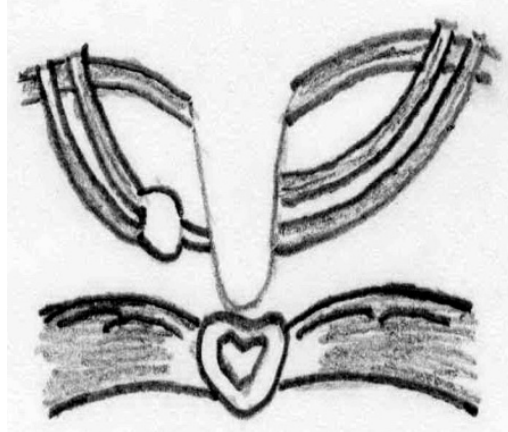

$\mathrm{B}$

Рис. 6. Схема складних форм пілонідальних нориць за Т.Н. Зубайдовим (2017): А - I ступінь; Б - II ступінь; В - III ступінь [23]

У 2018 р. групою дослідників запропонована так звана PLLATIN класифікація (за першими літерами кожної із класифікаційних ознак), яка побудована з позицій можливого діагностично-лікувального алгоритму:

$\checkmark$ Proximity to anus (близькість до заднього проходу у см).

$\checkmark$ Length from distal to proximal sinus; in recurrences scar length (відстань між проксимальним та дистальними синусами у см).

$\checkmark$ LATeral openings from midline (бічна відстань від нориці до середньої лінії у см).

$\checkmark$ Infection retention (binary) (обмеження інфекціï) $\mathrm{TAK}=1$ та $\mathrm{HI}=0$.

$\checkmark$ Number of previous definitive surgery attemps (кількість попередніх оперативних втручань [3].

Обговорення результатів. Приступаючи до формування класифікаційних ознак ПХ у дітей, ми чітко усвідомлювали можливість первинної відсутності в цій групі пацієнтів деяких ознак, які притаманні для дорослого віку, і в тому числі через меншу тривалість існування "активного" періоду захворювання.

Також нами враховувався той очевидний факт, що тривалість існування ПХ в дитячому віці, на відміну від дорослих пацієнтів, значно коротша, в переважній більшості це лише період пубертатного періоду. Так як тривалість пубертатного періоду не перевищує декількох років, вважаємо за недоцільне виділення у дітей хронічної форми ПХ, натомість слід відокремити період формування вторинних нориць, який в своєму перебігу складається із трьох стадій: інфільтрації $\Rightarrow$ рецидиву абсцесу $\Rightarrow$ гнійної нориці.

При морфометричному дослідженні анатомічної структури зовнішнього сфінктера відхідника була визначена відсутність типової округлої структури, натомість його структура в просторовому плані має еліпсоподібну форму, витягнуту в передньозадньому напрямку із переважанням м'язової каудальної порції. Середні лінійні розміри підшкірної порції сфінктера у напрямках 3 `, 6`, 9` та $12^{`}$ у положенні на спині складали відповідно 18,45 \pm 0,21 мм, 26,68 \pm 0,68 мм, 18,45 $\pm 0,21$ мм, 23,91 $\pm 0,36$ мм. На основі цього встановлено, що «зона небезпеки» навколо анального сфінктера, при пошкодженні якої можуть виникнути порушення довільного утримання кишкових газів та калу, має чіткі межі. Підшкірна порція зовнішнього анального сфінктера має форму еліпса, зміщеного каудально 3 передньо-заднім розміром $50,59 \pm 1,04$ мм та 3 поперечним розміром $36,90 \pm$ 0,42 мм, проведеними через центр анального отвору (рис. 7) [9]. 


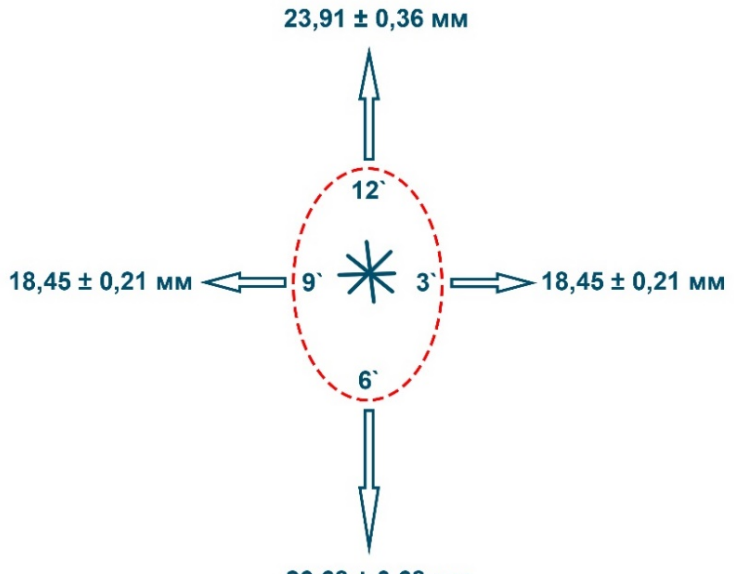

$26,68 \pm 0,68$ мм

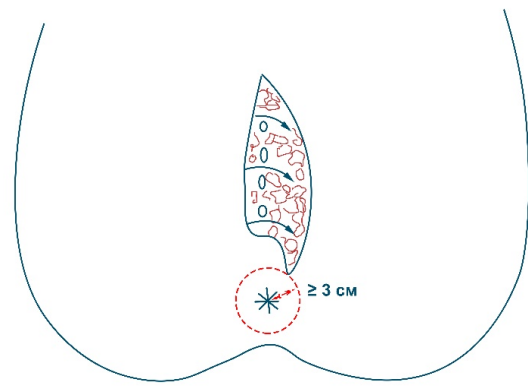

Б

Рис. 7. Схема локалізації зовнішнього сфінктера відхідника: А - лінійні розміри підшкірної порції зовнішнього сфінктера відхідника; Б - оптимальні межі інтраопераційного доступу при ПХ у дітей

Це свідчить про те, що при виконанні доступу під час радикальної операції з приводу ПХ дистальний край останнього варто "завершувати" на відстані мінімум 3 см від анального отвору, а не $2 \mathrm{~cm}$, як це рекомендують деякі фахівці. Особливо звертає на себе той факт, що при проведенні операцій за cleft lift методикою хірургу необхідно мобілізувати шкіру та м'які тканини зі сторони медіального розрізу, верхнього та нижнього країв операційної рани. Це призводить до того, що волокна підшкірної порції сфінктера іще більше пошкоджуються за рахунок їх препарування від основної товщини м язу та додаткового розсічення. Так як волокна підшкірної порції зовнішнього сфінктера відхідника можуть через це пошкоджуватись у зоні проведення операції, то в подальшому можливе виникнення порушення його

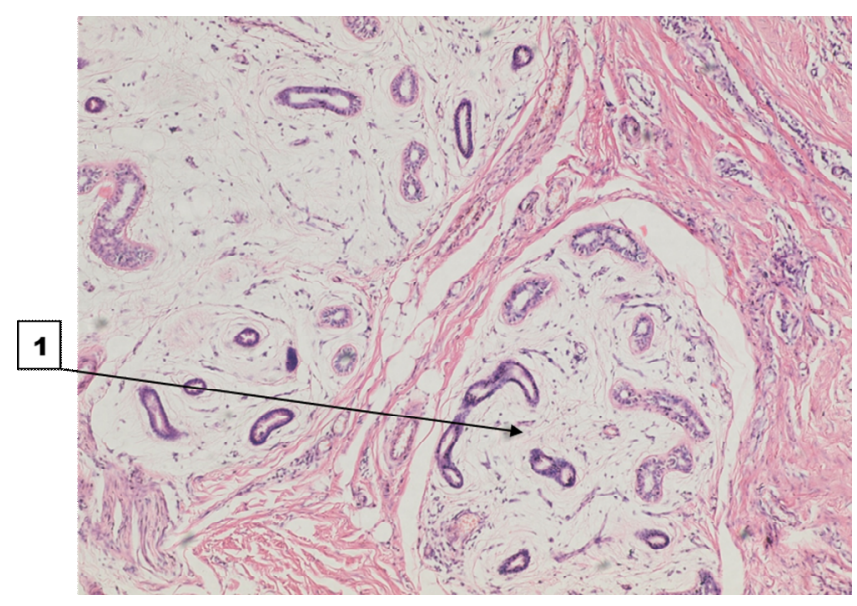

Мезенхімальна тканина існує тільки в ембріональному періоді розвитку людини, повністю витрачаючись на утворення тканин зародня. Після народження в організмі людини зберігаються лише мало диференційовані клітини в складі пухкої волокнистої сполучної тканини (клітини адвентиції), які можуть дивергентно диференціюватись у різних напрямках, але в межах певної тканинної системи. Враховуючи сутність природи мезенхімальної тканини, ії вікову та функціональну потенцію, уявлення про "мезенхіму функції, що спричинятиме зниження якості життя пацієнта.

Звернувши увагу на факт розбіжностей у розумінні та трактуванні етіопатогенезу ПХ, було проведено детальне морфологічне вивчення структурної будови видалених інтраопераційно куприкових кіст у дітей та дорослих. У процесі дослідження встановлено, що на відміну від дорослих, майже у 50\% дітей спостерігався притаманний тільки їм, характерний морфологічний чинник у вигляді незрілої мезенхімоподібної тканини, серед якої в великій кількості зустрічались додатки шкіри (потові залози апокринового типу, деформовані волосяні фолікули 3 великою кількістю волосяних стрижнів), які глибоко розташовувались в оформленій фіброзній тканині та не були пов'язані зі шкірою (рис. 8).

Рис. 8. Хибно розвинуті додатки шкіри в ділянці епітеліально-куприкових ходів: 1 - додатки шкіри (деформовані волосяні фолікули 3 великою кількістю волосяних стрижнів), розташовані серед набряклої незрілої мезенхімоподібної тканини 3 незначним хронічним неспецифічним запаленням, які розташовані глибоко в оформленій фіброзній тканині та не пов'язані зі шкірою. Забарвлення: гематоксилін та еозин. 3б.: × 100

дорослого" неспроможне, так як в складі диференційованого організму незмінені клітини зародня, в нормі, не зберігаються.

Проведений розділ досліджень показав, що наявність певних морфологічних чинників ПХ у дітей, таких як наявність мезенхімальної тканини, відмінності будови стінки куприкової кісти від дорослих та відсутність чіткого підтвердження трансдермального проникнення волосяних стрижнів у стінку та 
порожнину епітеліальної куприкової кісти свідчать на користь вродженої етіології захворювання [8].

Враховуючи досвід попередників в намаганні створити класифікації ПХ, певні особисті дані клініко-морфологічних досліджень та результати роздумів над клінічними ознаками патології, ми запропонували наступні клінічно орієнтовані класифікаційні ознаки захворювання у дітей на основі особливостей етіопатогенезу, притаманних для цього віку пацієнтів.

Кожна із рубрик класифікаційних ознак побудована 3 урахуванням їх можливого практичноорієнтованого використання в діагностичнолікувальному алгоритмі ПХ у дітей, особливо відповідно до безпосереднього вибору способу оперативного втручання, як єдиного радикального методу корекції патології.

\section{КЛАСИФІКАЦЙНІ ОЗНАКИ ПІЛОНІДАЛЬНОЇ ХВОРОБИ У ДІТЕЙ}

І. ЗА ПЕРІОДАМИ ПЕРЕБІГУ ПАТОЛОГІЇ:

1. Безсимптомний (неускладнений період);

2. Період ускладнень без вторинних нориць: стадія інфільтрату, абсцесу.

3. Період формування вторинних нориць.

4. Період загострення (рецидиву):

- рецидивний перебіг без лікування;

- періоди загострення після оперативних втручань.

II. ЗА ТОПОГРАФО-АНАТОМІЧНИМИ ОСОБЛИВОСТЯМИ СІДНИЧНО-КРИЖОВОКУПРИКОВОї ДІЛЯНКИ:

1. Варіанти конфігурації сідниць:

А. Низька (пласка); Б. Середня; В. Висока.

2. За складністю локалізації пілонідальних кіст:

А. Прості (в межах човникоподібної ділянки);

Б. Складні (поза умовною лінією співставлення сідниць):

- на сідничних ділянках (з одного або з обох боків);

- на поперековій ділянці;

- в межах перианальної ділянки.

3. За відстанню від заднього проходу:

А. Близькість дистальної нориці $>3 \mathrm{~cm}$;

Б. Близькість дистальної нориці $<3$ см;

В. Локалізація норицевих ходів у параректальних клітковинних просторах (пельвіоректальному, ішеоректальному, ретроанальному, перианальному).

Г. Локалізація норицевих ходів по відношенню до анальних сфінктерів (екстра-, транс-, інтер-, супрасфінктерні та нашкірні).

4. Позакрижово-куприкова локалізація пілонідального синусу.

III. ЗА НАСЛІДКАМИ ЛІКУВАННЯ:

1. Одужання.

2. Прості (поодинокі) ускладнення в проекції післяопераційної рани - поодинокий норицевий хід в межах човникоподібної ділянки без навколишніх грубих рубцевих змін;

3. Складні (множинні) ускладнення в проекції післяопераційної рани:

А. Ранні: - нагноєння або/та розходження країв рани; - розвиток флегмони крижово-куприкової та/або перианальної ділянок;

- утворення некротизуючих виразок післяопераційного рубця.

\section{Б. Пізні:}

- множинні норицеві ходи поза межами човникоподібної ділянки 3 навколишніми грубими рубцевими змінами та інфільтратами;

- деформуючі післяопераційні рубці в сіднично-крижово-куприковій ділянці;

В. Порушення замикальної функції сфінктерного апарату відхідника;

Г. Формування синдрому хронічного болю, мацерацій та/або свербежу шкіри в крижовокуприковій ділянці;

Д. Утворення вторинних нориць в параректальних клітковинних просторах.

Висновки. У сучасній хірургії дитячого віку існує нагальна необхідність у розробці та впровадженні в клінічну практику уніфікованих класифікаційних ознак пілонідальної хвороби, які забезпечать адекватні індивідуальні підходи до діагностики та вибору методів оперативного лікування захворювання 3 урахуванням сучасних світових поглядів на його етіопатогенез.

Відмінності класифікаційних ознак ПХ у дітей мають полягати у чіткому розумінні деяких морфологічних чинників етіопатогенезу, які притаманні даній віковій групі хворих, тривалості захворювання, особливостям перебігу та індивідуальних вікових анатомічних параметрів крижово-куприкової ділянки 3 урахуванням факту зростання індивідуума.

Використання в клінічній практиці розроблених класифікаційних ознак пілонідальної хвороби у дітей дозволить визначити клінічні варіанти перебігу захворювання та обрати найбільш оптимальну тактику хірургічного лікування.

\section{References:}

1. Allen-Mersh TG. Pilonidal sinus: finding the right track for treatment. Br J Surg. 1990; 77:123-132.

2. Bodnar OB, Randiuk RYu, Bodnar BM, ta in. Epitelialnyi kuprykovyi khid u ditei: kharakterystyka, osoblyvosti, metody likuvannia. Khirurhiia dytiachoho viku. 2019; 2(63):67-72.

3. Doll D. Another Pilonidal classification - PLLATIN. PSJ. 2018; 4:1-3.

4. Guner A, Cekic AB, Boz A, et al. A proposed staging system for chronic symptomatic pilonidal sinus disease and results in patients treated with stage-based approach. BMC Surgery. 2016; 16(18):1-8.

5. Irkorucu O. Managemen for pilonidal disease: before you compare, use a classification system. Asian J Surg. 2016; 39(4):260-261.

6. Irkörücü OE, Reyhan E. The best therapy for pilonidal disease: which management for which the? World J Surg. 2012; 36:691-692.

7. Karakaş DÖ, Yilmaz I, Hazer B, et al. A new approach to classification of pilonidal disease. Turk $\mathrm{J}$ Colorectal Dis. 2017; 27:65-66.

8. Konoplitskyi V, Shavluik R, Dmytriiev D, et al. Pilonidal disease: changes in understanding of etiology, pathogenesis and approach to treatment. Wiad Lek. 2019; 72(8):1559-1565.

9. Konoplitskyi VS, Shavliuk RV. Anatomichne obgruntuvannia khirurhichnoho dostupu pry 
pilonidalnii khvorobi u ditei. Klinichna anatomiia ta operatyvna khirurhiia. 2019; 18(3):70-74.

10. Korablina SS. Kompleksnyj podkhod k lecheniyu epitelialnogo kopchikovogo khoda [disertatsiya]. Stavropol: Stavr. gos. med. un-t; 2014. P.128.

11. Lavreshin PM, Nikulin DYu, Korablina SS. Diagnostika i lechenie epitelialnogo konchikovogo khoda. Mediczinskij vestnik Severnogo Kavkaza. 2011; 4:99-103.

12. Lurin IA, Czema EV. Etiologiya i patogenez pilonidalnoj bolezni: obzor literatury. Koloproktologiya. 2013; 3:35-50.

13. Notaras MJ. A review of three popular methods of treatment of postanal (pilonidal) sinus disease. $\mathrm{Br} \mathrm{J}$ Surg. 1970; 57(12):886-890.

14. Pomazkin VI, Mansurov YuV. Vybor operaczii dlya lecheniya bolnykh s epitelialnym kopchikovym khodom. Vestnik khirurgii. 2008; 167(1):85-87.

15. Pomazkin VI. Analiz rezultatov lecheniya epitelialnogo kopchikovogo khoda pri differenczirovannom vybore operaczii. Uralskij mediczinskij zhurnal. 2010; 4:36-39.

16. Popkov OV, Ginyuk VA, Alekseev SA, i dr. Epitelialnyj kopchikovyj khod. Metody khirurgicheskogo lecheniya. Voennaya mediczina. 2017; 1:101-106.

17. Poverin GV, Evdokimov AN. Kisty kopchika u detej (klinika, diagnostika i khirurgicheskoe lechenie). Rossijskij vestnik detskoj khirurgii, anesteziologii i reanimatologii. 2019; 9(2):105-120.

18. Quinodoz PD, Chilcott M, Grolleau J-L, et al. Surgical treatment of sacrococcygeal pilonidal sinus disease by excision and skin flaps: the toulouse experience. Eur J Surg. 1999; 165:1061-1065.

19. Rudin EP, Evloeva RKh, Gorneva NN, Aparina YuE. Vybor taktiki khirurgicheskogo lecheniya epitelialnogo kopchikovogo khoda $\mathrm{v}$ zavisimosti ot vyrazhennosti vospalitelnogo proczessa. Byulleten VSNCz SO RAMN. 2011; 4(80),2:147-151.

20. Tezel E. A new classification according to navicular area concept for sacrococcygeal pilonidal disease. Colorectal Disease. 2007; 9:572-576.

21. Yurkiv OIe, Tsema YeV. Suchasnyi pohliad na prychyny vynyknennia ta likuvannia pilonidalnykh ta dermoidnykh kist kryzhovo-kuprykovoi dilianky. Ukrainskyi naukovo-medychnyi molodizhnyi zhurnal. 2018; 1:30-37.

22. Zhdanov AI, Krivonosov SV, Brezhnev SG. Khirurgicheskoe lechenie epitelialnogo kopchikovogo khoda: kliniko-anatomicheskie aspekty. Vestnik eksperimentalnoj i klinicheskoj khirurgi. 2013; 6(3):386-392.

23. Zubajdov TN. Khirurgicheskoe lechenie slozhnykh form epitelialnogo kopchikovogo khoda [disertatsiya]. Dushanbe: Tadzh. derzh. med. un-t; 2017. P.132.

\section{УДК 611.711.8-089-053}

\section{РАЗМЫШЛЕНИЯ О КЛАССИФИКАЦИОННЫХ ПРИЗНАКАХ ПИЛОНИДАЛЬНОЙ БОЛЕЗНИ У ДЕТЕЙ}

\section{В.С. Коноплицкий, Р.В. Шавлюк}

Винницький национальный медицинский университет им. Н.И. Пирогова, кафедра детской хирургии, 2. Винница, Украина, ORCID ID: 0000-0001-9525-1525, e-mail:vkonoplytsky@gmail.com

Резюме. До сих пор не разработано единой концепции о причинах возникновения пилонидальной болезни, возможности её моделирования и понятной единой классификации, что является ключем к основательному пониманию данной патологии. Унифицированная классификация пилонидальной болезни должна учитывать развитие, течение и особенности клинических форм, за счет чего формируется клинический диагноз, что помогает выбрать наиболее оптимальный индивидуальный способ и план лечения.

Цель работы: разработать клинически ориентированные классификационные признаки пилонидальной болезни с учетом особенностей детского возраста.

Результаты исследования: путём объединения опыта предшественников, собственных исследований и размышлений нами предложены клинически ориентированные классификационные признаки заболевания у детей на основе особенностей этиопатогенеза присущих этому возрасту пациентов. Для этого были учтены основные отличия детской группы пациентов от лиц взрослого возраста: невозможность в силу их возрастных особенностей длительного течения заболевания, наличие морфометрических особенностей строения наружного анального сфинктера, наличие незрелой мезенхимоподобной ткани в полости пилонидальной кисты.

\section{Выводы:}

1. В современной хирургии детского возраста существует настоятельная необходимость в разработке и внедрении в клиническую практику унифицированных классификационных признаков пилонидальной болезни.

2. Различия классификационных признаков пилонидальной болезни у детей должны заключаться в наличии ряда морфологических, этиопатогенетических, анатомических и клинических отличий от лиц взрослого возраста.

3. Использование разработанных классификационных признаков пилонидальной болезни у детей позволит определить клинические варианты течения заболевания и выбрать наиболее оптимальную тактику хирургического лечения.

Ключевые слова: пилонидальная болезнь, дети, классификация, детская хирургия. 
UDC 611.711.8-089-053

\section{REFLECTIONS ON CLASSIFICATION SIGNS OF PILONIDAL DISEASE IN CHILDREN}

\author{
V.S. Konoplitskyi, R.V. Shavliuk
}

National Pirogov Memorial Medical University,

Vinnytsya, department of pediatric surgery,

Vinnytsya, Ukraine,

ORCID ID: 0000-0001-9525-1525,

e-mail:vkonoplytsky@gmail.com

Abstract. The history of knowledge about pilonidal disease has been going on for more than 150 years, and so far no single concept has been developed on the cause, modeling and clear single classification, which is the key to a thorough understanding of this pathology. The experience of modern medical science shows that the best treatment results are achieved when it is possible to model the pathological process. Unfortunately, for pilonidal disease, there is currently no reproducible experimental model. This negatively affects the ability to achieve the desired results in the treatment of this disease in both adults and children.

The concept «pilonidal disease» is quite wide and consists of a set of pathological manifestations that are formed under the influence of adverse anatomical physiological factors (congenital and acquired) and external factors. The final morphological substrate for the implementation of pilonidal disease is the formation of pilonidal cysts.

The classification pilonidal disease should take into account the development, course and features of clinical forms, due to and on the basis of which a clinical diagnosis is formed. This helps to choose the most optimal individual method and treatment plan.

Purpose: on the basis of the factual material accumulated over more than 150 years of history to develop clinically oriented classification features of pilonidal disease, taking into account the characteristics of childhood.
Materials and methods. The paper deals with all currently available published concepts of the occurrence of pilonidal disease, its variants and proposals for the formation of classifications of pilonidal disease. The most "popular" theories of the development of this disease by both foreign and blighty authors were developed.

Results of research. To date, there are a large number of separate classifications of pilonidal disease, which are often formed on the basis of one or two specific features or based on external manifestations of pathology of the sacrococcygeal region. There are also some classifications based on combinations of some of the features./ On the basis of combination of experience of predecessors, own researches and reflections we offered clinically oriented classification signs of a disease at children on the basis of features of an etiopathogenesis of patients characteristic of this age. First of all, the main differences of the pediatric group of patients from adults were taken into account: impossibility due to age features of the long course of the disease, presence of morphometric features of the external anal sphincter structure, presence of immature mesenchymal tissue in the pilonidal cyst cavity. The classification proposed by us combines all the main aspects of the disease and proposes to classify pilonidal disease: by periods of this pathology, by topographic and anatomical features of the buttocksacrococcygeal region and the consequences of treatment.

\section{Conclusions:}

1. In modern pediatric surgery there is an urgent need to develop and implement in clinical practice unified classification features of pilonidal disease.

2. Differences in the classification of pilonidal disease in children should be a number of morphological, etiopathogenetic, anatomical and clinical differences from adults.

3. The use in clinical practice of the developed classification features of pilonidal disease in children will determine the clinical variants of the disease and choose the most optimal tactics of surgical treatment.

Keywords: pilonidal disease, children, classification, pediatric surgery. 